\title{
Adrenal haemorrhage in the new born: revisited.
}

\author{
Rushaid N.A. Al-Jurayyan", Amal A. Al-Hakami ${ }^{2}$, Nasir A. M. Al- Jurayyan ${ }^{\text {* }}$ \\ ${ }^{1}$ College of Medicine, King Saud University, Kingdom of Saudi Arabia \\ ${ }^{2}$ College of Medicine, Princess Nourah Bint Abdulrahman University, Kingdom of Saudi Arabia
}

\begin{abstract}
Background: Adrenal haemorrhage (AH) in the new-born is not that uncommon and has been reported frequently. AH occurs most often after a traumatic delivery or complicated neonatal course. Design and setting: A retrospective, hospital-based study conducted at king Khalid university hospital (KKUH), endocrine service, Riyadh, Saudi Arabia, during the period January 2014 and July 2018. Methods: Medical records of neonates who had been diagnosed to have AH were reviewed. Data included age, sex, clinical manifestations, laboratory and radiological investigations.

Results: During the period under review, five neonates were diagnosed to have adrenal haemorrhage. All were term male infants, who were delivered vaginally .one baby was large for gestational age (LGA), and three babies had perinatal hypoxemia. Clinical symptoms were not specific and diagnosis was confirmed by performing abdominal sonography (USG).

Conclusion: AH should be recognised in the new-borns with nonspecific symptoms who had potential risk factors. Abdominal ultrasonography (USG) should be performed to diagnose $\mathrm{AH}$, and monitor its progress. Adrenal hormone testing also should be performed.
\end{abstract}

Keywords: Adrenal haemorrhage, Neonate, Hormone, Ultrasonography, Clinical presentation.

Accepted on October 29, 2018

\section{Introduction}

Adrenal haemorrhage $(\mathrm{AH})$ is a relatively rare disorder with variable and non-specific presentation which may cause acute adrenal crisis, shock, and death if not recognized early and appropriately treated [1-3].

AH may occur at any age, with non-traumatic bilateral extensive $\mathrm{AH}$ more often in the elderly at the time of acute stressful situations. In contrast, patient with traumatic $\mathrm{AH}$ typically occurs in children and adolescent patients with adrenal haemorrhage may die because of underlying disease or associated complications. The mortality rate was estimated to be approximately $15 \%$. However, this could be varying with the severity of the underlying disorder. For example, in patients with waterhouse Friderichson syndrome occurring with sepsis has even a higher rate [4-8].

The diagnosis should be suspected in any stressful situations like in the post-operative period, pregnancy, or in presence of a coagulopathy in conjunction with hypotension, and electrolyte disturbance. Also it is known to be associated with antiphospholipid syndrome, amoebic liver abscess, and bacterial sepsis [9-14].

$\mathrm{AH}$ in the new-born is a well described entity and has been reported frequently. It occurs during the first weeks of life. The haemorrhage occurs most often after a traumatic delivery or neonatal course complicated by hypoxia, hypertension or coagulopathy [15-18].

In this article, we report five patients with adrenal haemorrhage (AH) in the neonatal period who were diagnosed and confirmed by abdominal ultrasonography (USG). The clinical management and outcome were also discussed.

\section{Material and Methods}

This retrospective hospital based study was conducted in newborns who were diagnosed to have $\mathrm{AH}$ at King Khalid University Hospital (KKUH), Riyadh, Saudi Arabia during the period January 2014 and July 2018. Medical records were reviewed for demographic characteristic, clinical presentation and predisposing causes. Laboratory and radiological investigation were extracted. Ultrasonography (USG) was performed at the time of diagnosis and for follow up to determine the resolution time. Random serum adrenocorticotrophic (ACTH) and cortisol were performed supplemented by short synacthen test (ACTH stimulation test).

\section{Results}

Five neonates were diagnosed with adrenal haemorrhage in the period between January 2014 and July 2018. All were term male infants who were delivered vaginally. One large for 
gestational age, birth weight was $4.510 \mathrm{~g}$, and three had perinatal hypoxia.

Clinical presentation was non-specific; however, abdominal ultrasonography (USG) (Figures 1 and 2) suggested the diagnosis. Two babies showed signs and symptoms of adrenal insufficiency which were confirmed by hormonal testing. They were treated with glucocorticoids therapy.

(A)

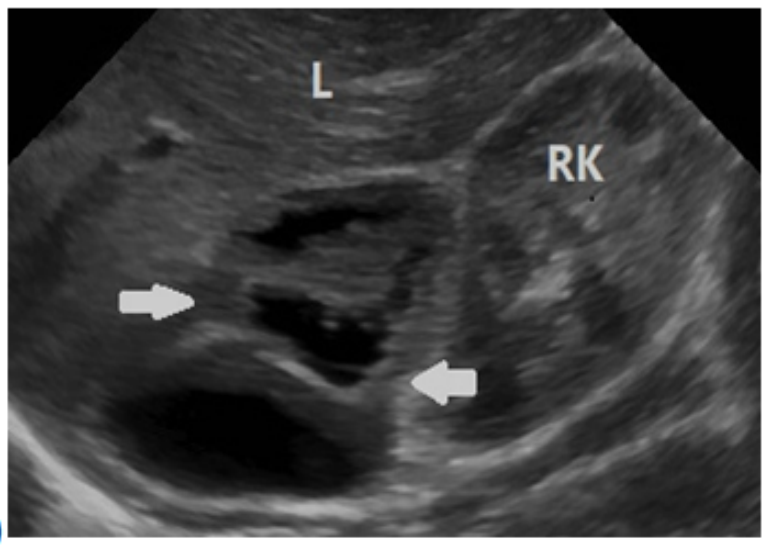

(B)

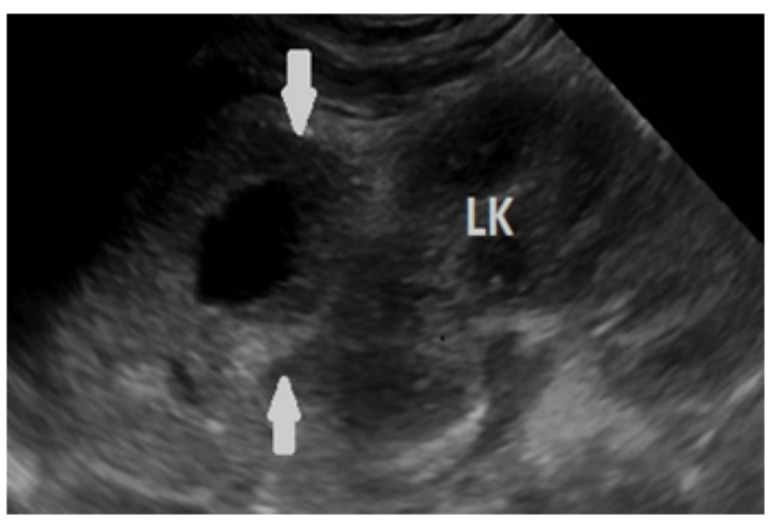

Figure 1. Abdominal ultrasound demonstrates (A) right adrenal gland and (B) left adrenal gland complex lesions in keeping with hemorrhage (white arrows). RK: Right Kidney; LK: Left Kidney; L: Liver.

Demographic characteristics, presenting symptoms, predisposing risk factors and laboratory data were shown in Table 1. The haemorrhage resolved within a mean of $12.6 \mathrm{w}$ (range: 8-20).

\section{Discussion}

Adrenal haemorrhage ( $\mathrm{AH})$ is relatively a frequent finding in the term male infants delivered vaginally. The incidence of $\mathrm{AH}$ ranges from 1.7 per 1000 autopsied new-born infants to approximately $3 \%$ of infants subjected to screening by abdominal ultrasonography (USG). The reason for such a high incidence being the large size of adrenal gland relative to body weight. The gland is almost two times larger. Also, fifty to sixty arterial branches from the three suprarenal arteries supplying the gland. This is highly vascular supply drains into medullary sinusoids via relatively few venous channels, thereby creating a potential vascular damage. Any condition leading to reduce oxygen supply (hypoxia) may lead to shunting of blood flow, and damage to endothelial making them more prone to haemorrhage, an example of this is congenital adrenal hyperplasia [1-3,16-29]. The most important predisposing cause of $\mathrm{AH}$ were birth trauma, prolonged labour, intrauterine infections, perinatal asphyxia or hypoxia, large birth weight, septicaemia, and haemorrhagic disorders.

(A)

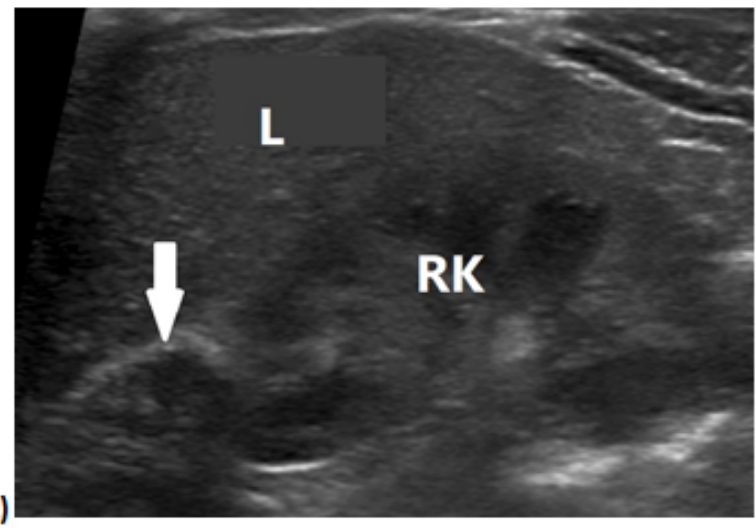

(B)

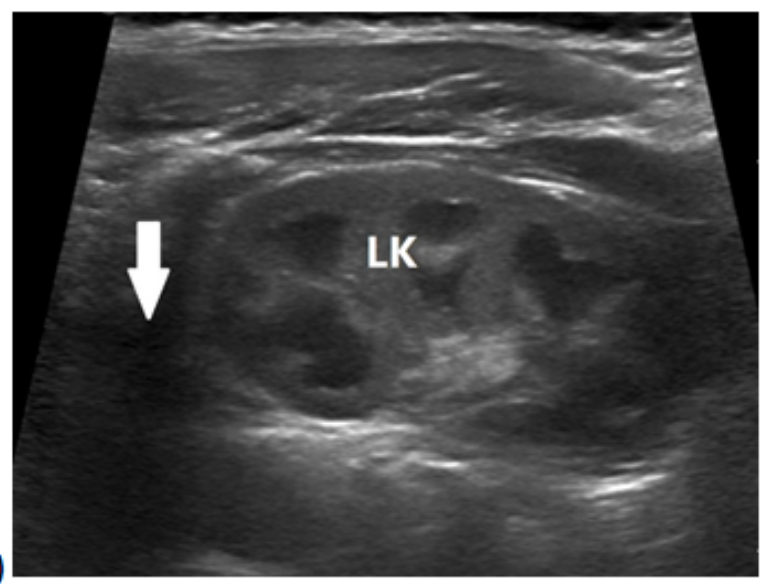

Figure 2. Two months follow up abdominal ultrasound demonstrates (A) interval decrease in size of the right adrenal gland hemorrhage (white arrows) and (B) complete resolution of the left adrenal gland hemorrhage (white arrows). RK: Right Kidney; LK: Left Kidney; L: Liver.

The clinical manifestations of A.H. vary from asymptomatic to life threatening conditions with hypovolemia, hypotension and shock. The clinical presentation in our series was nonspecific. However, persistent neonatal jaundice, flank mass, scrotal swelling and haematuria, anaemia, hypo or hypertension, cyanosis, urinary tract infections and may be adrenal insufficiency with shock. The most common presentation includes neonatal jaundice, due to the breakdown of red blood cells in the hematoma [1,5-7,15-18,21-31]. The nature of adrenal haemorrhage, in this series was bilateral. In contrast to Ruminiska et al. [16] who reported the predominance of right sided haemorrhage and Demirel et al. who showed that right sided adrenal haemorrhage being the most common $(72.2 \%)$ in 33 patients. Two infants developed adrenal insufficiency 
requiring steroid therapy. This was similar to other reports $[1,16-18,23,32]$.

Table 1. Demographic characteristic, presenting signs, risk factors and laboratory finding in infants with AH.

\begin{tabular}{|c|c|c|c|c|c|c|c|c|}
\hline $\begin{array}{l}\text { Patient } \\
\text { number }\end{array}$ & Sex & Gestational age & Birth weight & $\begin{array}{l}\text { Mode } \\
\text { delivery }\end{array}$ & of & Presenting signs & Risk factors & Laboratory results \\
\hline \multirow[b]{2}{*}{1} & \multirow[b]{2}{*}{ M } & \multirow[b]{2}{*}{$38 w$} & \multirow[b]{2}{*}{$2820 \mathrm{~g}$} & \multirow{2}{*}{\multicolumn{2}{|c|}{ V }} & \multirow[b]{2}{*}{----} & \multirow[b]{2}{*}{ Hypoxia } & Cort; 120 \\
\hline & & & & & & & & ACTH \\
\hline \multirow[b]{2}{*}{2} & \multirow[b]{2}{*}{ M } & \multirow[b]{2}{*}{$38 w$} & \multirow[b]{2}{*}{$2960 \mathrm{~g}$} & \multirow[b]{2}{*}{ V } & \multirow{2}{*}{\multicolumn{2}{|c|}{ Pallor hypotension }} & \multirow[b]{2}{*}{ Hypoxia } & Cort; 140 \\
\hline & & & & & & & & АСТН \\
\hline \multirow[b]{2}{*}{3} & \multirow[b]{2}{*}{ M } & \multirow[b]{2}{*}{$40 w$} & \multirow[b]{2}{*}{$3560 \mathrm{~g}$} & \multirow[b]{2}{*}{ V } & \multirow{2}{*}{\multicolumn{2}{|c|}{ Pallor hypotension }} & \multirow[b]{2}{*}{ Hypoxia } & Cort; 200 \\
\hline & & & & & & & & ACTH 12.6 \\
\hline \multirow{2}{*}{4} & \multirow{2}{*}{ M } & \multirow{2}{*}{$42 w$} & \multirow{2}{*}{$4510 \mathrm{~g}$} & \multirow{2}{*}{ V } & \multirow{2}{*}{\multicolumn{2}{|c|}{ Lethargy, hypotension }} & \multirow{2}{*}{$\begin{array}{l}\text { Birth trauma, Shoulder } \\
\text { dystocia }\end{array}$} & Cort; 65 \\
\hline & & & & & & & & АCTH 29.5 \\
\hline \multirow{3}{*}{5} & \multirow{3}{*}{ M } & \multirow{3}{*}{$39 w$} & \multirow{3}{*}{$3210 \mathrm{~g}$} & \multirow{3}{*}{ V } & \multirow{3}{*}{\multicolumn{2}{|c|}{$\begin{array}{l}\text { Pallor, lethargy, } \\
\text { electrolyte disturbance }\end{array}$}} & \multirow{3}{*}{ Birth trauma, Erb's polsy } & Cort; 85 \\
\hline & & & & & & & & ACTH 20.5 \\
\hline & & & & & & & & High renin \\
\hline
\end{tabular}

M: Male, V: Vaginal, Cort: Cortisol (nmol/L N=130-630), ACTH: Adrenocorticotrophic Hormone (pmol/L N=4.6-13.9), w: Week, g: Gram.

$\mathrm{AH}$ should be considered in the differential diagnosis of abdominal flank mass. It may be extremely difficult to differentiate $\mathrm{AH}$ from renal pathology such as hydronephrosis, cystic renal disease, vascular thrombosis, or a neuroblastoma. Abdominal ultrasound (USG) may help to differentiate a haemorrhage from other pathology [5,33]. Serial USG will show an interval of resolution of A.H., but persistence or enlargement of the mass might indicate other pathology. Ultrasonography also might diagnose prenatal adrenal gland haemorrhage [34]. The resolution time of $12.6 \mathrm{w}$ (range: $8-20$ ) is comparable to what have been reported [16,18,23]. Furthermore, with the modern imaging particularly computed tomography (CT)-and magnetic resonance imaging (MRI) the diagnosis of $\mathrm{AH}$ is frequently made easily [35-37]. Positron emission tomography (PET) scan could be of value in diagnosis [38].

In conclusion $\mathrm{AH}$ should be suspected in the new born infants with non-specific symptoms who had potential risk factors. Abdominal ultrasonography (USG) should be performed to diagnose the condition of $\mathrm{AH}$, and monitor its prognosis. Furthermore adrenal hormone testing is also important.

\section{Acknowledgment}

The authors would like to thank Miss Hadeel N. Al-Jurayyan for her help in preparing the manuscript.

\section{References}

1. Bornstein SR, Allolio B, Arlt W, Barthel A, DonWauchope A, Hammer GD. Diagnosis and treatment of primary adrenal insufficiency: an endocrine society clinical practice guideline. J Clin Endocrinol Metab 2016; 101: 364-389.

2. Abdullah KG, Stitzlein RN, Tallman TA. Isolated adrenal hematoma presenting as acute right upper quadrant pain. $\mathrm{J}$ Emerg Med 2012; 43: 215-217.

3. May CJH, Asia M, Karavitaki N, Arlt W, Guest P, OReilly MW. Bilateral adrenal haemorrhage. QJM Int J Med 2017; 169-171.

4. Canacci AM, MacLennan GT. Adrenal hemorrhage. J Urol 2007; 178: 284-287.

5. Vella A, Nippoldt TB, Morris JC. Adrenal hemorrhage: a 25-year experience at the Mayo Clin Proc 2001; 76: 161-168.

6. Picolos MK, Nooka A, Davis AB, Raval B, Orlander PR. Bilateral adrenal hemorrhage: an overlooked cause of hypotension. J Emerg Med 2007; 32: 167-169.

7. You JS, Chung SP, Park YS, Chung HS, Lee HS, Yu JS. Isolated adrenal hemorrhage after minor blunt trauma. Am J Emerg Med 2007; 25: 984.

8. Bornstein SR. Predisposing factors for adrenal insufficiency. N Engl J Med 2009; 360: 2328-2339.

9. Kent PD, Gregoire JR. Amebic liver abscess complicated by bilateral adrenal hemorrhage and adrenal insufficiency. Hosp Phys 2000; 36: 73-76.

10. Keizer AL, Peters LW, Vries C, Smets YF, de Wit LT, van Pampus MG. Spontaneous adrenal haemorrhage in early pregnancy. BMJ Case Reports 2013.

11. Caron P, Chabannier MH, Cambus JP, Fortenfant F, Otal $\mathrm{P}$, Suc JM. Definitive adrenal insufficiency due to bilateral adrenal hemorrhage and primary antiphospholipid syndrome. J Clin Endocrinol Metab 1998; 83: 1437-1439. 
12. Gowda D, Shenoy V, Malabu V, Cameron D, Sangla K. Bilateral adrenal gland haemorrhage: an unusual cause. Endocrinal Diabetes Metab Case Rep 2004.

13. Marti VL, Miller J, Sosa JA, Roman SA, Carling T. Spontaneous adrenal haemorrhage with associated masses: etiology and management in 6 cases and a review of 133 reported cases. World J Surg 2012; 36: 75-82.

14. Adem PV, Montgomery CP, Husain AN, Koogler TK, Arangelovich V, Humilier M, Boyle-Vavra S, Daum RS. Staphylococcus aureus sepsis and the WaterhouseFriderichsen syndrome in children. N Engl J Med 2005; 353: 1245-1251.

15. Chang TA, Chen CH, Liao MF, Chen CH. Asymptomatic Neonatal Adrenal Hemorrhage. Clin Neonatol 1998; 512: 23-26.

16. Ruminska M, Welc-Dobies J, Lange M, Maciejewska J, Pyrzak B, Brzewski M. Adrenal haemorrhage in neonates: risk factors and diagnostic and clinical procedure. Med Wieku Rozwoj 2008; 12: 457-462.

17. Abdu AT, Kriss VM, Bada HS, Reynolds EW. Adrenal hemorrhage in a new-born. Am J Perinatol 2009; 26: 553-557.

18. Demirel N, Bas AY, Zenciroglu A, Tasci-Yildiz Y. Adrenal bleeding in neonates: report of 37 cases. Turk J Pediatr 2011; 53: 43-47.

19. Simon DR, Palese MA. Clinical update on the management of adrenal hemorrhage. Curr Urol Rep 2009; 10: 78-83.

20. Iwatani S, Takeoka E, Mizobuchi M, Yoshimoto S, Nakao H. Congenital adrenal hyperplasia: a possible risk factor for neonatal adrenal hemorrhage. J Med Cases 2014; 519: 486-487.

21. Adorisio O, Mattei R, Ciardini E, Centonze N, Noccioli B.Neonatal adrenal hemorrhage mimicking an acute scrotum. J Perinatol 2007; 27: 130-132.

22. Goksugur SB, Bekdas M, Yorgun M, Altunhan H, Karatas Z, Dilek M, Demircioglu F. A rare cause of hypertension in a newborn: adrenal hemorrhage. Nat J Physiol Pharm Pharmacol 2015; 5: 157-159.

23. Mutlu M, Karagüzel G, Aslan Y, Cansu A, Okten A. Adrenal hemorrhage in newborns: a retrospective study. World J Pediatr 2011; 7: 355-357.

24. Qureshi UA, Ahmad N, Rasool A, Choh S. Neonatal adrenal hemorrhage presenting as late onset neonatal jaundice. J Indian Assoc Pediatr Surg 2009; 14: 221-223.

25. Gyurkovits Z, Maroti A, Renes L, Nemeth G, Pal A, Orvos H. Adrenal haemorrhage in term neonates: a retrospective study from the period 2001-2013. J Matern Fetal Neonatal Med 2015; 28: 2062-2065.

26. Ongun EA, Ongun H. Adrenal hemorrhage mimicking of cyanotic disorders in newborns. Iran J Pediatr 2017; 27: 7791.
27. Habeb AM, Zulali M, Yamani AS, Yassine SM. Neonatal adrenal hematoma with urinary tract infection: Risk factor or a chance association? Saudi J Kidney Dis Transplant 2014; 25: 376-380.

28. Wang CH, Chen SJ, Yang LY, Tang RB.Neonatal adrenal hemorrhage presenting as a multiloculated cystic mass. J Chin Med Assoc 2008; 71: 481-484.

29. Taide DV, Bendre PS, Redkar R, Hambarde S.Adrenal masses associated with Beckwith Wiedemann syndrome in the newborn. Afr J Paediatr Surg 2010; 7: 209-210.

30. Gunlemez A, Karadag A, Degirmencioglu H, Uras N, Turkay S. Management of severe hyperbilirubinemia in the newborn: adrenal hematoma revisited. J Perinatol 2005; 25: 803-804.

31. Bancos I, Hahner S, Tomlinson J, Arlt W. Diagnosis and management of adrenal insufficiency. Lancet Diabetes Endocrinol 2015; 3: 216-226.

32. Jordan E, Poder L, Courtier J, Sai V, Jung A, Coakley FV. Imaging of non-traumatic adrenal haemorrhage. Am J Roentgenol 2012; 199: 91-98.

33. Knorr M, Evans D. Bedside ultrasound of acute adrenal hemorrhage. Am J Emerg Med 2012; 30: 2088.

34. Vollersen E, Hof M, Gembruch U. Prenatal sonographic diagnosis of fetal adrenal gland hemorrhage. Fetal Diagn Ther 1996; 11: 286-291.

35. Sacerdote MG, Johnson PT, Fishman EK. CT of the adrenal gland: the many faces of adrenal hemorrhage. Emerg Radiol 2012; 19: 53-60.

36. Tan GX, Sutherland T. Adrenal congestion preceding adrenal hemorrhage on CT imaging: a case series. Abdom Radiol (NY) 2016; 41: 303-310.

37. Manganaro L, Al Ansari N, Barchetti F, Saldari M, Vitturini C, Glorioso M, Buonocore V, Barchetti G, Maccioni. Bilateral adrenal hemorrhage in a patient with myelodysplastic syndrome: value of mri in the differential diagnosis. Case Rep Radiol 2013; 479836.

38. Repko BM, Tulchinsky M. Increased F-18 FDG uptake in resolving atraumatic bilateral adrenal hemorrhage (hematoma) on PET/CT. Clin Nucl Med 2008; 33: 651-653.

\section{*Correspondence to}

Nasir A. M. Al-Jurayyan

Consultant Paediatric Endocrinologist

College of Medicine

King Saud University

Kingdom of Saudi Arabia 